\title{
THE FUNCTIONING OF THE WORK SAFETY MANAGEMENT SYSTEM IN A SELECTED ENTERPRISE AND THE PROBLEM OF EMPLOYEE PARTICIPATION
}

\author{
Anna GEMBALSKA-KWIECIEŃ \\ Silesian University of Technology, Faculty of Organization and Management, Institute of Economics \\ and Informatics, Poland; Anna.Gembalska-Kwiecien@polsl.pl; ORCID: 0000-0001-9275-0447
}

Purpose: The presented article deals with the analysis of the functioning of the work safety management system in hard coal mining in the example of a selected mine. The basic elements that make up the safety management system are presented, with particular emphasis on employee participation.

Design/methodology/approach: Empirical research was conducted in the form of a questionnaire addressed to employees. Literature research of the subject was carried out.

Findings: In a modern enterprise, all employees, at all levels, must be involved in creating the desired safety culture. Every regular employee must realistically see respect and compliance with OHS regulations by the supervision and the top management of the Mine.

Practical implications: The issues raised in the article significantly affect the improvement of preventive methods related to work safety, including environmental conditions and work organisation, as well as attitudes and behaviour of employees.

Originality/value: In safety management, the greatest attention should be devoted to man as the subject of all activities. Because it is the human factor that causes most accidents, and the other factors, often referred to as the work factor, lose their relevance when new technologies and materials are used to provide greater safety.

Keywords: safety management, accidents at work, human factor, motivation to work safely.

Category of the paper: Research paper.

\section{Introduction}

Accident prevention methods and techniques have undergone many subsequent changes, conditioned by views on the causes of accidents. The transition from fatalism to modern accident prevention and safety management was made gradually by learning the causes of the occurring accidents and the role of man in causing them. However, the most important factor in creating modern rules for preventing accidents at work was the growing awareness of the 
possibilities of taking effective preventive measures to prevent human and material losses. Man first had to get to know the nature that surrounds him, so that he could understand that accidents are not the result of fatalistic force majeure, but are the result of his own errors, both predictable and avoidable.

As information on the causes of accidents was obtained, theories and views explaining their origins changed. In the initial period, they were perceived as accidental events or as a result of the appearance of unpredictable force majeure in technical systems, referred to by the Latin name "vis maior". Then the human participation in causing accidents was noticed (Heinrich, and Petersen, 1987), and then their sequential course. This made it possible to build a "chain" model of an accident recognized as a consequence of mistakes made due to a deficit of motivation, knowledge and experience, the effect of specific personality traits, health status or tasks that are excessively difficult in stressful situations (Bieniok, 2004; Lewandowski, 2000; Studenski, 1996; Gembalska-Kwiecień, 2017). In accordance with modern safety management concepts, it is recommended to use preventive technical, organisational and psychological measures. In addition to the technical and organisational activities to date, it has become important to equip people with knowledge, experience, and especially the motivation for conducting safe behaviour and to avoid risk.

The hard coal mining industry recorded 1076 total accidents, including 8 fatal (WUG). Occurring accidents, their consequences and poor health of employees (caused by work in unfavourable conditions of the material work environment) are the causes of significant financial losses for the victims, their employers and the whole society.

Therefore, the question arises - What actions should be taken to effectively achieve the improvement of the state of safety in the enterprise? The author hopes that the following study will contribute to obtaining the answer.

\section{Safety management as an element of business management}

R.W. Griffin claims that "management definitions are probably as numerous as books on the subject" (Griffin, 2000). This means that there is a differentiated approach to management issues. In the public perception, management is mainly connected with the governance understood as exercising power - making decisions. According to R.W. Griffin, "Management is a set of activities including: planning and making decisions, organising, leading, i.e. managing people and controlling organisations focused on resources (human, financial, material, informational) with the intention of achieving the organisation's goals in an efficient and effective manner" (Griffin, 2000). According to the given definition, activities related to the implementation of the goal are called management. The essence of the problem lies in the methods of achieving the given goal in an efficient and effective way. 
Safety is a state, in which a protected object is free from the effects of threats. Under real conditions, safety is a desirable state (the limit of our aspirations), but unlikely (elimination of all threats). For this reason, it is necessary to determine the conditions that can be considered as a safe state. The need to set a border is the reason for developing regulations and recommendations. An example of this is labour legislation, which sets working conditions that protect the interests of the employee as a weaker person in relation to the employer.

The primary goal of safety management is to protect people's health and life in an efficient and effective manner. This requires the use of appropriate methods, taking into account existing conditions.

According to R. Studenski, safety management is a practical, interdisciplinary activity that uses knowledge of system theory, organisation and management, accident and illness prevention, psychology, as well as ergonomics in creating safe working conditions and raising the ability and motivation of people to apply safety principles at work and outside of it (Studenski, 1996).

According to J. Lewandowski, safety management is a set of management functions that is decisive in specifying and implementing safety policy in the workplace (Lewandowski, 2000).

Z. Pawłowska writes, that occupational health and safety management includes those aspects of general management, that are associated with the development and implementation of occupational health and safety policy. The efficiency of this management as a skilful control of resources, processes and information, in order to achieve the intended results has a decisive impact on the achieved level of occupational health and safety (Pawłowska, 1997).

According to D. Petersen, safety management, in a general meaning, consists of: assessing the state of safety, creating programmes to reduce accidents and occupational diseases, managing material resources to spend on these purposes, monitoring and correcting the implementation of the objectives set in preventive programmes (Petersen, 1988). In a narrower sense, it covers activities related to analysing, designing and monitoring the functioning of the safety system, as well as those of its components that affect the risk of loss of life or health.

The mission of the vast majority of enterprises is to generate profit or at least achieve satisfaction with their business. Activities related to ensuring safety are seen as an additional burden on the enterprise. For this reason, despite the verbal declaration on the priority of safety over production, safety occupies a low position in the hierarchy of priorities when making decisions in enterprises. In Gasparski's research, the chief executives of enterprises were presented with a list of 12 criteria that can be used to make decisions (Gasparski, 1992).

The most important priorities are: profit, enterprise development, the possibility of using production capacity, earnings of the crew. The "work safety" criterion came in 9th place, ahead of only the prestige of the enterprise, its own satisfaction with new products and the recognition of its superiors. 
The low position of work safety can be explained by the lack of knowledge or the possibility of choosing preventive methods that reduce the losses resulting from the activation of threats. Outlays incurred by employers to meet legal requirements is treated as an excessive burden on enterprises. According to Directive 89/391/EEC, “increasing safety, improving hygiene and health protection at work is an objective which should not be subordinated to purely economic considerations". Comparing the results of tests, regulations and recommendations, it can be formulated that effective safety management is not possible without assessing the economic effects of the lack in safety and without forecasting the likely losses caused by failure to take necessary preventive measures.

It is worth emphasising, that more and more mining plants recognise the need to develop and implement modern principles and systems for managing work safety.

\section{Requirements for the OHS Management System}

The Occupational Health and Safety Management System in enterprises is becoming more and more important, due to the growing awareness and importance of safety-related problems, not only in the surroundings of the organisation, but also in the company's most important resource, i.e. the human resource.

The personal commitment of top management is a prerequisite for achieving success, which is the implemented and effectively functioning occupational health and safety management system. For everything to be done correctly and efficiently, top management should show strong and clear leadership and a commitment to OHS activities.

The occupational health and safety policy is a specific declaration of the organisation, regarding its intentions and principles relating to the general effects of OHS activities. It sets the framework for action and setting the organisation's goals for OHS management.

Occupational Health and Safety policy should express the organisation's commitment to:

- prevention of potentially accidental occurrences, occupational diseases, and accidents at work,

- striving for continuous improvement of OHS at work,

- implementation of legal requirements, as well as other organisation requirements,

- continuous improvement of all OHS activities,

- guaranteeing the right resources and means to implement the policy,

- taking into account the role of employees and their involvement in OHS activities and raising their qualifications.

Top management is responsible for defining, documenting, implementing and updating the OHS policy, as well as announcing it to all employees and ensuring that they are understood by them (PN - N - 18001, 2014). 


\section{Forms of employee involvement in the management system}

According to B. Błaszczyk, three levels of participation can be distinguished: co-decision, consultation and information.

Co-decision is the widest level of participation. It is characterised by high employee involvement in the decision-making process. Employees have the opportunity to express their objection or veto decisions that are unfavourable to them, and their opinion is taken into account in the final steps (Reykowski, 1975; Stoner, and Wankel, 1996).

Consultation or "seeking advice, joint consultation" is another level of participation. Employees have less influence on the decision made. Consultations with employees or their representatives "may be mandatory or voluntary for management, and there may be an obligation to consult certain decisions or to block the enforceability of certain decisions in the absence of agreement reached as a result of consultations" (Benedikt, 2002; Aburumman et al., 2019; Forsyth, 2000).

The last level of participation is information, characterised by low employee impact on the decision made and their low involvement. In the company, as in the case of consulting, there may be an obligation to inform the employee about decisions made before they are taken, or it may be done on a voluntary basis. However, from the point of view of participation, it is important for the employee concerned to be informed.

Participation levels can also be divided into passive and active forms, that is cooperation and co-decision. Within cooperation, we can specify:

- information (manifested by the right to obtain information),

- listening (covering complaints, various postulates),

- expressing oneself (disclosing one's opinion on a given topic and counselling).

However, co-decision can be divided into: the right to object (the possibility of vetoing decisions), the right to consent (approval of decisions accepted by the employee), the right to joint settlement (active participation in solving problems) and the right to exclusive decision making (independent decision-making).

There are also three main types of participation:

- full participation - characterised by the fact that each employee has an impact on the decision-making process. Their views and expressed opinions are taken into account and are reflected in the final decision.

- partial participation - there are at least two decision groups in the organisation, that have the opportunity to participate in discussions, but only one of them has the right to make the final decision.

- pseudo-participation - the manifestation of participation is the necessity of the employee to receive a broad and unambiguous justification for making such a decision. 
Creating a suitable atmosphere for the development and proper functioning of participatory tools depends on several basic conditions, that are interrelated with each other.

The first important factor is the recruitment process. When selecting the team of staff attention should not only be paid to their respective professional qualifications or experience, but also to character traits that would favour the use of participatory management style. Among these features, one can include: desire for independence and freedom of action, willingness to take responsibility for making decisions, identification with the organisation's goals, knowledge and experience sufficient to deal with the problem, experience with previous supervisors resulting in a positive attitude to the participatory style of management (Kożusznik, 2005; Erdal et al., 2018).

Another condition is teamwork, which consists in "a collective effort directed towards achieving common goals" (Penc, 2000; Robbins, and DeCenzo, 2002). Teamwork must be based on the mutual trust of the people in the group, positive relationships between supervisors and employees, mutual respect and recognition that success depends on everyone.

Participation entails a number of changes in the organisation, which are often reluctant to be received by managers and employees and have a huge impact on management styles practiced in the enterprise. There are several ways to limit this negative aspect of participation:

- ensuring that employees accept the changes - convincing them of the benefits of introducing changes, involving employees in the change process (real participation),

- encouraging new ideas - creating an atmosphere in the organisation, that would allow employees to reveal their ideas, kindly accepting any idea coming from employees and implementing solutions signalled by employees,

- facilitating mutual contacts - proper communication between groups, cooperation between groups, freedom of information flow,

- tolerating failures - in case of disappointment resulting from failures, one should avoid reprimands, and instead give additional advice, talk about the problem revealed,

- setting clear goals and ensuring the freedom to achieve them - in the participatory management style, employees must have a certain margin of discretion in making decisions that will enable them to demonstrate their qualifications and skills,

- ensuring acknowledgment - thanks to this, employees are aware that their effort has been noticed and appreciated, and all types of rewards will be an incentive to continue to engage in the company's affairs.

The next condition for the proper development of participation is an appropriate information and communication system. Lack of access or obstructing access to information can be a huge barrier in solving problems. "In practice, lack of information means no impact on the course of events, hence a faulty system of information and communication between organisational units prevents the phenomenon of participation at all" (Dusak, and Vrcek, 2002). However, communication is necessary to verify and evaluate the information obtained. 
The content and organisation of work is also a very important factor influencing the development of participation. Employee involvement in the decision-making process is possible when the work performed is not monotonous or routine. When performing work, within the imposed procedures, the employee performs restoration work. However, in a situation where a certain freedom of action is allowed, a creative element appears in the work performed.

Another element that has a significant impact on participation is the process of introducing changes. People usually complain and comment on the changes introduced. The main reasons for this behaviour are:

- habits - it is more convenient for employees to work in familiar conditions, where work is already a habit,

- conformism - people like to comply with accepted ways of work and behaviour, any changes in the working environment are suspicious for them and cause anxiety,

- misunderstanding - as a result of poor communication, it may turn out that employees do not understand the introduced changes and believe that, as a consequence, they may lose a lot,

- threat to their own interests - people rarely believe that the introduced change can bring them any individual benefits, they tend to catch the negatives of change rather than its positives,

- rumours - changes are often preceded by various types of rumours and gossips, which unfortunately exaggerate the negative aspects of the planned undertaking,

- lack of commitment - changes that are imposed on employees without the opportunity to discuss them are very often negatively perceived by them and the employees show no interest in them (Mendel, 2001).

To reduce employee resistance that occurs when introducing changes, one can use participatory persuasion methods.

The last condition in enabling participation is the use and the raising of professional qualifications and their development. Highly qualified employees are significantly more often and more actively involved in decision-making processes, but on the other hand, the participatory management style enables people with lower qualifications to develop and be able to demonstrate themselves.

\section{Benefits of employee participation in a safety management system}

The top management of each organisational unit must realise that "management is simply too important to be left to managers and encourage employees to cooperate". The term "management" in this context refers to both the entire organisation and safety related 
matters. All possibilities of employee involvement in the company's affairs, especially those related to safety management, increase the integration of employees with the company and bring many benefits (Reiman et al., 2019; Gaurenau et al., 2019).

Participation of employees in making safety related decisions increases satisfaction with the work performed and causes the person to identify oneself with the company. Engaging employees in problems not only related to their daily duties means that they themselves are beginning to broaden their horizons of interest and think about improving the prevailing working conditions. The awareness that they have an impact on the functioning of the enterprise gives them satisfaction and willingness to act. However, for employees to want to get involved in the organisation's matters, they must obtain certain benefits from it, which often include money, all kinds of praise from the management team, a sense of acknowledgment, independence or the possibility of their own development. It is also necessary to satisfy the need for employee subjectivity, by granting them a due place in the organisation and taking their interests into account in all the enterprise's activities (Samarth, and Kumar, 2018; Stemn et al., 2019; Tappura et al., 2019). The possibility of co-decision means that employees shape non-standard and creative behaviours, which often implies a non-standard approach to the tasks they solve.

The enterprise, thanks to the involvement of employees, only benefits from it, because the increase in employee satisfaction due to participation translates into their effectiveness and efficiency, and thus the company's efficiency. This is proven through studies carried out by the European Foundation for the Improvement of Living and Working Conditions as part of the EPOC project - "Employee Participation in Organisational Change". The project concerned 10 countries of the European Union and was implemented in 1993-1998. The obtained results confirmed the economic benefits for companies resulting from employee participation. It was found that, as a result of employee involvement, costs were reduced (in about $40 \%$ of private companies), quality improved (in about $90 \%$ of companies), production increased (in about $40 \%$ of companies), number of diseases decreased (in about $30 \%$ of companies) or absenteeism decreased (in around 35\% of companies) (Sisson, 2000). In order for enterprises to achieve even better results in this field, they should remember about the possibilities of benefiting from participation right from the course of the recruitment process. One should not only pay attention to education and experience, but also to the personality of the candidate. People with suitable personality traits can be an important link in a company's development. Summing up the above benefits, the company can only achieve them thanks to a properly selected team of staff, characterised by creative thinking and creativity, which are the basis of innovation.

Employee participation in the safety management system, apart from the benefits mentioned above, has a great impact on improving the functioning of this system. Employee involvement in activities related to occupational health and safety and the ability to make decisions independently causes employees to identify themselves with the company and the decisions 
they make. Therefore, the company should develop a participatory system, placing more emphasis on the direct participation of employees in matters related to the system, because they can not only help in solving problems, but also affect the better operation of the implemented system.

\section{Research results}

In order to obtain additional information regarding the significance of the Safety Management System in the Hard Coal Mine (KWK), an interview was conducted with the Safety Engineer. According to the Engineer, accidents are usually caused by ill-thought behaviour of employees. Many cases testify to this. Sometimes employees do not understand that their actions also threaten others. Therefore, before an employee is hired for work, they are sent for occupational health and safety training at the expense of the Mine, and then preliminary training. They usually take the form of a lecture, seminar or course. Later, when, for example, significant legal changes take place, they are sent for a course, lecture or training seminar of an educational nature, which should end with a test of knowledge of the discussed subject. However, the Engineer's observation shows that most future employees ignore this concern for their safety in the future. Future employees go to those trainings because they want to work in the Mine, but they lack commitment.

The Mine has a procedure, Monitoring of Occupational Health and Safety, according to which, natural hazards are monitored by automatic systems using cyclical measurements of exposures occurring in the work environment, and are later documented and every employee has access to them. As far as technical threats are concerned, they are monitored during inspection and supervision of given workstations, with the use of technical documentation. The inspection results are also documented. In turn, monitoring of personal hazards is based on an analysis of employee behaviour during supervision and inspection of work performed, potentially accidental events and accidents occurred at work.

The Mine is up to date in Occupational Health and Safety Management Systems. In 2011, the Integrated Management System was recertified. As for the initial activities, in 2000 it was decided to implement the system due to the growing number of accidents, the Certificate of Occupational Health and Safety Management System in the basic level. It lasted until December 2006, before the implementation of the First Certificate was completed, in November 2006 it was decided to implement the Second Certificate. It lasted until November 2009. The next step was obtaining the TUV Nord Certificate. The First Certificate was obtained in the period from September 2005 to September 2009. Then, the Second Certificate from September 2008 to September 2011. Currently, the Mine has implemented and still uses all the basic series of ISO standards. 


\section{Final conclusions}

The above article deals with the analysis of the Safety Management System at the Mine under examination by analysing the documentation of the Enterprise Safety Management System, analysis of accidents at work in 2011-2018, and empirical research in the form of a survey conducted among physical workers regarding knowledge of the SMS, attitudes and commitment to safety and an interview with the Mine safety Engineer.

As a result of the research, the following conclusions were drawn:

- Research carried out in the Hard Coal Mine (document KWK) regarding accident analysis shows that the introduction of a Safety Management System has contributed to reducing the number of accidents. Accident analysis for 2011-2018 reveals a significant decrease in the number of accidents.

- The most common occupational diseases in the surveyed company are pneumoconiosis and hearing impairment. Less common diseases are chronic musculoskeletal disorders, vibration white finger has been eliminated in individual cases as a result of automation of manual work. In the case of occupational diseases, a downward trend can be observed.

- To reduce the number of occupational diseases in the Hard Coal Mine, prevention projects were developed jointly with the Institute of Occupational Medicine and Environmental Health in Sosnowiec. As a result of cooperation and conducted trainings, diagnosis and systemic prevention, the number of occupational diseases associated with hearing impairment stabilised.

- Document analysis, as well as the interview with the Safety Engineer, showed that the Mine is up to date with the Occupational Health and Safety Management Systems. In 2011, the Integrated Management System was recertified. Currently, the Mine has implemented and still uses all the basic series of ISO standards.

- The Mine has a procedure, Monitoring of Occupational Health and Safety, according to which natural hazards are monitored through automatic systems, using cyclical measurements of exposures occurring in the work environment, then they are documented, and employees have access to them. Technical hazards are monitored during inspection and supervision of given workstations with the use of documented technical documentation. Monitoring of personal hazards is based on an analysis of employee behaviour during supervision and inspection of work performed, potentially accidental events and accidents occurred at work.

- According to the Safety Engineer, accidents are largely caused by erroneous behaviour of employees (employees often do not understand that their risky behaviour threatens others). Therefore, before an employee is hired for work, they are sent for occupational health and safety training at the expense of the Mine, and then preliminary training. 
They usually take the form of a lecture, seminar or course. Later, when, for example, significant legal changes take place, they are sent for a course, lecture or training seminar of an educational nature, which should end with a test of knowledge of the discussed subject. However, the Engineer's observation shows that most future employees ignore this concern for their safety in the future. Future employees go to those trainings because they want to work in the Mine, but they lack commitment.

- The Mine has implemented a Safety Management System, however, according to research, half of the employees do not know about it, additional training is needed here. However, if they do not bring satisfactory results, e.g. lack of interest of employees in the subject, it is recommended to apply appropriate punishment. It is necessary to develop awareness among the crew that only an employee working safely, i.e. in accordance with OHS regulations, can be promoted or receive a raise or bonus

- The Health and Safety Service and the Hard Coal Mine Management are developing a series of trainings aimed at continuous improvement and raising a safety culture among their subordinates. The Safety Management System shapes the safety culture, but it is a continuous process, and only then can it bring beneficial effects of changes in the long term, so that the level of accident rates is satisfactory.

- In safety management, the greatest attention should be devoted to man as the subject of all activities. Because it is the human factor that causes most accidents, and the other factors, often referred to as the work factor, lose their relevance when new technologies and materials are used to provide greater safety.

- In a modern enterprise, all employees, at all levels, must be involved in creating the desired safety culture. Every regular employee must realistically see respect and compliance with OHS regulations by the supervision and the top management of the Mine.

- According to empirical research, the problem of employee participation in the Mine leaves a lot to be desired. Employees are not interested in engaging in solving safety problems, rather they are characterised by some passivity. Improving this state of affairs is necessary and lies with both management and the crew.

- It also seems necessary to stimulate healthy motivation for safe work among the crew, through its activation and implementation of jointly developed solutions.

- The right selection for the job and the correct process of professional adaptation of the employee. Devoting a lot of attention to them during this time, and elimination of employees who do not comply with OHS rules and regulations, as well as those with tendencies to risky behaviour.

- Training on OHS issues should be conducted in a diverse form of communication, in an interesting and understandable way for a specific recipient. They should involve participants in discussions and problem solving, stimulate their creativity in accordance 
with applicable regulations. They should respond to the listeners' demand for topics and issues raised. Trainings should always, without exception, end with a test of theoretical knowledge and, as far as possible (depending on the subjects discussed), a practical test of newly acquired skills.

\section{Acknowledgements}

This paper was financed from the resources of the Silesian University of Technology, project no. BK-235/ROZ-1/2020 (13/010/BK_20/0042).

\section{References}

1. Aburumman, M., Newman, S., and Fildes, B. (2019). Evaluating the effectiveness of workplace interventions in improving safety culture: A systematic review. Safety Science, 118, pp. 376-392.

2. Benedikt, A. (2002). Motywowanie pracowników w sytuacjach kryzysowych. Wrocław: Wydawnictwo Astrum.

3. Bieniok, H. (2004). Metody sprawnego zarządzania. Warszawa: Wydawnictwo Placet.

4. Data Wyższego Urzędu Górniczego, www.wug.gov.pl.

5. Dušak, V., Vrček, N. (2002). Technologie informacyjne jako niezbędny czynnik skutecznej komunikacji w czasie realizacji projektu. Wydawnictwo Politechniki Śląskiej.

6. Erdal, M., Isik, N.S., and Firat, S. (2018). Evaluation of occupational safety culture in construction sector in the context of sustainability. Lecture Notes in Civil Engineering, 1, pp. 245-254.

7. Forsyth, P. (2004). Jak motywować ludzi. Gliwice: Wydawnictwo Helion.

8. Găureanu, A., Draghici, A., Dufour, C., and Weinschrott, H. (2019). The Organizational Safety Culture Assessment. Advances in Intelligent Systems and Computing, 876, pp. 728-734.

9. Gasparski, P. (1992). Kadra kierownicza wobec ryzyka zawodowego pracowników. In: Psychologia i bezpieczeństwo pracy. Warszawa: PAN, Instytut Psychologii.

10. Gembalska-Kwiecień, A. (2017). Czynnik ludzki w zarządzaniu bezpieczeństwem pracy w przedsiębiorstwie. Wybrane zagadnienia. Gliwice: Wydawnictwo Politechniki Śląskiej.

11. Griffin, R. (2000). Podstawy zarządzania organizacjami. Warszawa: PWN.

12. Heinrich, H., and Petersen W. (1987). Industrial accidents with STEP. New York: M. Dekker. 
13. Kożusznik, B. (2005). Kierowanie zespołem pracowniczym. Warszawa: PWE.

14. Lewandowski, J. (2000). Zarządzanie bezpieczeństwem pracy w przedsiębiorstwie. Łódź: Wydawnictwo Politechniki Łódzkiej.

15. Mendel, T. (2001). Partycypacja w zarządzaniu współczesnymi organizacjami. Poznań: AE.

16. Mine internal documents KWK.

17. Penc, J. (2000). Motywowanie w zarządzaniu. Kraków: Wydawnictwo Profesjonalnej Szkoły Biznesu.

18. Petersen, D. (1988). Safety Management - A Humam Approach. New York: Aloray Inc.

19. Pawłowska, Z.(1997). Zarzadzanie bezpieczeństwem i higiena pracy. Bezpieczeństwo pracy i ergonomia, tom II. Praca zbiorowa. D. Koradecka (ed.). Warszawa: CIOP.

20. PN - N - 18001, System zarządzania bezpieczeństwem i higieną pracy - wymagania, 2014.

21. Robbins, S.P., and DeCenzo, D.A. (2002). Podstawy Zarzadzania. Warszawa: PWE.

22. Reykowski, J. (1975). Teoria motywacji a zarzadzanie. Warszawa: PWE.

23. Reiman, A., Pedersen, L.M., Väyrynen, S., Sormunen, E., Airaksinen, O., Haapasalo, H.A., and Räsänen, T. (2019). Safety Training Parks - Cooperative Contribution to Safety and Health Trainings. International Journal of Construction Education and Research, 1, pp. 19-41.

24. Samarth Ramprasad, K., and Kumar, P. (2018). 3 factor - Hot (human, organizational and technical) model for construction safety culture. International Journal of Civil Engineering and Technology, 8, pp. 520-541.

25. Sisson, K. (2000). EPOC - New Forms of Work. Can Europe Realize Its Potential. Ireland.

26. Stemn, E., Bofinger, C., Cliff, D., and Hassall, M.E. (2019). Examining the relationship between safety culture maturity and safety performance of the mining industry. Safety Science, 113, pp. 345-355.

27. Stoner, J.A.F., and Wankel, Ch. (1996). Kierowanie. Warszawa: PWE.

28. Studenski, R. (1996). Organizacja bezpiecznej pracy w przedsiębiorstwie. Gliwice: Wydawnictwo Politechniki Śląskiej.

29. Tappura, S., Teperi, A.M., Kurki, A.L., and Kivistö-Rahnasto, J. (2019). The management of occupational health and safety in vocational education and training. Advances in Intelligent Systems and Computing, 785, pp. 450-461. 